\title{
Modeling of patient-specific three semicircular canals
}

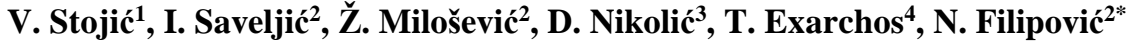 \\ ${ }^{1}$ Faculty of Medical Science, University of Kragujevac, Serbia \\ e-mail: vladislava.stojic@gmail.com \\ ${ }^{2}$ Faculty of Engineering, University of Kragujevac, Serbia \\ e-mail: fica@kg.ac.rs \\ ${ }^{3}$ Bioengineering Research and Development Center - BioIRC, Kragujevac, Serbia \\ ${ }^{4}$ University of Ioannina, Greece \\ e-mail: themis.exarchos@gmail.com \\ *corresponding author
}

\begin{abstract}
The semicircular canals (SCC) are fluid-filled inner ear structures designed to detect circular or angular motion. In this study we modeled three-dimensional biomechanical model of SCC and compared results with real patient case for the Benign Paroxysmal Positional Vertigo (BPPV) disease. The model consists of full 3D fluid-structure interaction incorporating particles, wall, cupula deformation and endolymph fluid flow. Full Navier-Stokes equations and continuity equations are used for fluid domain with Arbitrary-Lagrangian Eulerian (ALE) formulation for mesh motion. For cupula deformation with fluid coupling, fluid-structure interaction is used. The numerical results are compared with real experiment for BPPV test and cupula deformation for head manoeuvre from 0 to $30^{\circ}$. The results could be used for better understanding of BPPV disease diagnosis.
\end{abstract}

Keywords: biomechanical model of SCC, fluid-structure interaction, BPPV, sedimenting particle

\section{Introduction}

The semicircular canals detect motion by the motion of fluid in a spinning dish. At first, the fluid does not move when the dish is spun. Once the fluid has begun to spin, however, it continues to do so, even if the dish is no longer spun. This is due to inertia, whereby a body remains at rest or continues in uniform motion until acted upon by an outside force. Movement of the hair cells in the semicircular canals causes the sensory cells to send a stream of action potentials to the eighth cranial nerve that leads to the vestibular nuclei in the brainstem. Benign paroxysmal positional vertigo (BPPV) is the most commonly diagnosed vertigo disease which implies the existance of basophilic particles in the semicircular canals (Berthoz 2004). Threedimensional eye movement recordings and selective semicircular canal inactivation have been used to investigate the spatial organization of vestibular signals in the vestibulo-ocular reflex. In this study the focus is on the semicircular canals, fluid-filled inner ear structures designed to detect circular or angular motion. For example, if a person is rolling at high speed in an 
airplane, performing ballet spins, or spinning in a circle, circular motion is detected with these canals. Sometimes this sense of moving in a circle may lead to dizziness or, in extreme cases, even nausea. The person whose motion-sensing system is not functioning properly often suffers from a condition known as vertigo and feels that they are spinning even when they are not (Baloh et al. 1993, Nuti et al. 1998). Each ear contains three semicircular canals. Each canal is oriented in a different plane that corresponds to a major rotation axis of the head in space. Details on the vestibular system elements are presented in Figure 1.

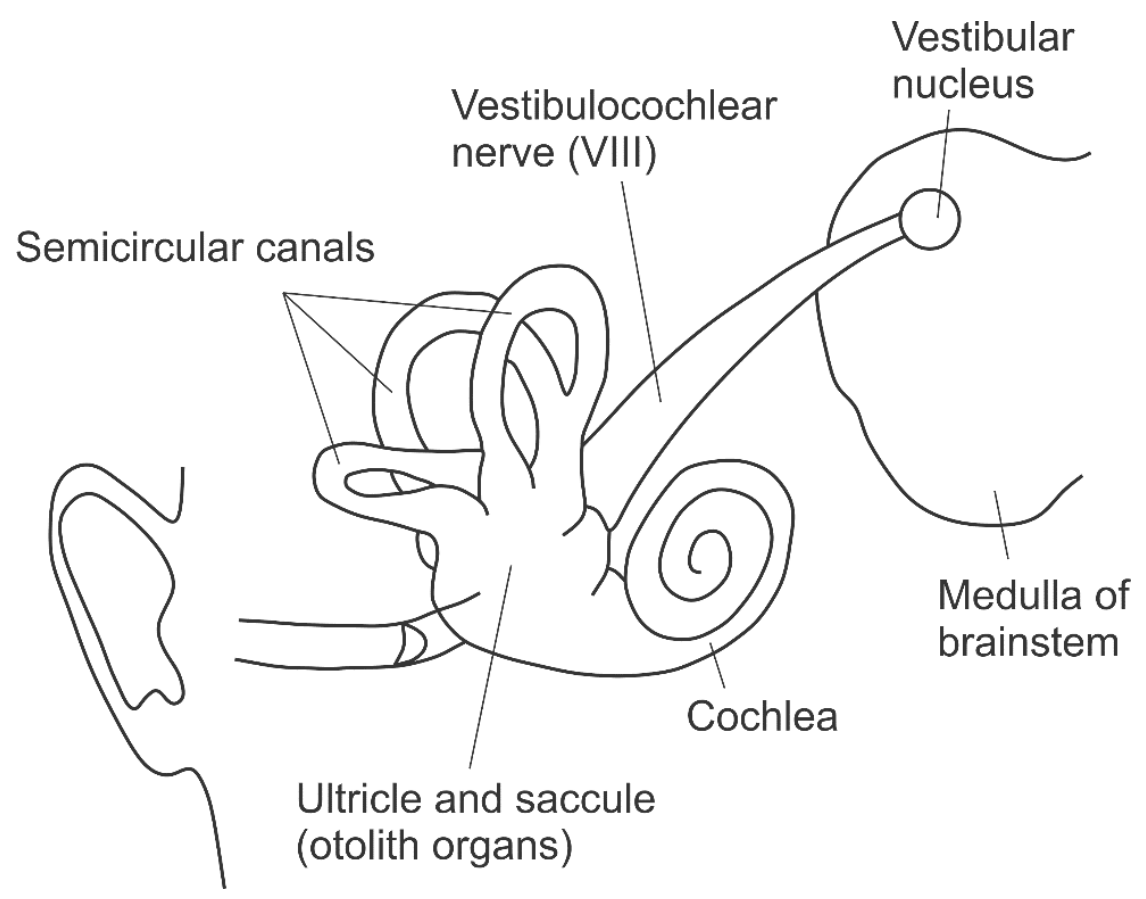

Fig. 1. Vestibular system

The connections from the left horizontal canal that mediate the vestibulo-ocular reflex (VOR) when that canal is excited are presented in Fig. 2. 


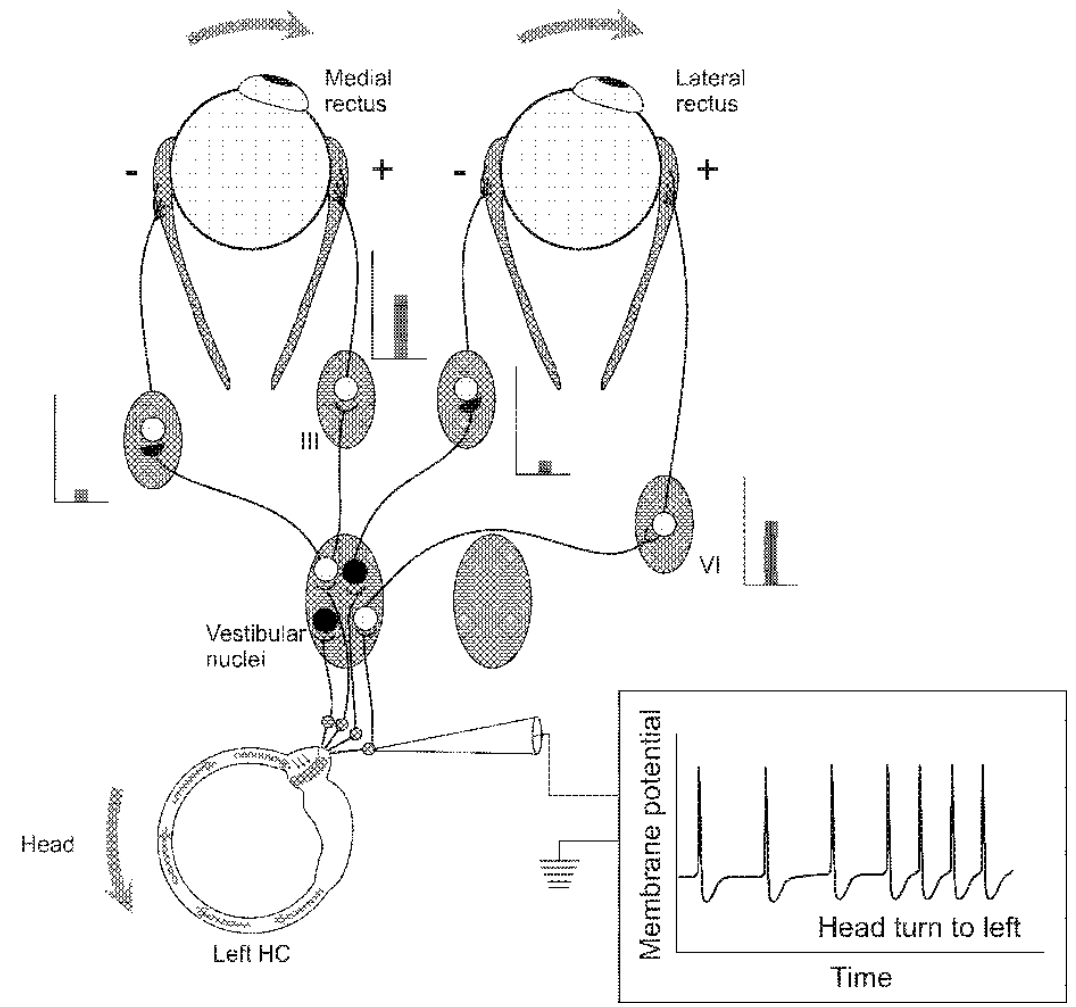

Fig. 2. Neural connections in the direct pathway for the vestibulo-ocular reflex (VOR) from excitation of the left horizontal canal (HC)

This movement excites the afferents from this canal; the inset demonstrates this increase in firing from the baseline rate. Secondary vestibular neurons in the ipsilateral vestibular (medial and superior) nuclei receive these afferent signals and connect to the ocular motor nuclei controlling the medial and lateral rectus muscles, which also lie roughly in a horizontal plane (Pagnini et al. 1989, Mergner et al. 1998). In this study, we firstly described numerical procedures for fluid flow and solid-fluid interaction. Then some examples for fluid velocity distribution with one or more otoconia particles for real patient specific are presented. The numerical results are compared with real experiment for BPPV test and cupula deformation for head manoeuvre from 0 to $30^{\circ}$, VOR gain for Right anterior with patient. It the end, some conclusions remarks are given.

\section{Methods and materials}

\subsection{Numerical procedures for fluid flow}

The governing equations for simulation of endolymph flow include the Navier-Stokes equations of balance of linear momentum and the continuity equation with application of ALE formulation as (Filipovic et al. 2006).

$$
\rho\left[v_{i}^{*}+\left(v_{j}-v_{j}^{m}\right) v_{i, j}\right]=-p_{, i}+\mu v_{i, j j}+f_{i}^{B}
$$




$$
v_{i, i}=\mathbf{O}
$$

where $V_{i}$ and $v_{i}^{m}$ are the velocity components of a fluid and of the point on the moving mesh occupied by the fluid particle, respectively; $\rho$ is fluid density, $p$ is fluid pressure, $\mu$ is dynamic viscosity, and $f_{i}{ }^{B}$ are the body force components (gravity). The symbol "* " denotes the mesh-referential time derivative, i.e. the time derivative at a considered point on the mesh,

$$
()^{*}=\left.\frac{\partial()}{\partial t}\right|_{\xi_{i}=\text { const }}
$$

and the symbol “ ${ }_{, i}$ ” denotes partial derivative.

We use $X_{i}$ and $\xi_{i}$ as Cartesian coordinates of a generic particle in space and of the corresponding point on the mesh, respectively. The repeated index means summation, from 1 to 3, i.e. $\mathrm{j}=1,2,3$ in Eq. 1, and $\mathrm{i}=1,2,3$ in Eq. 2. In deriving Eq. 1 we used the following expression for the material derivative (corresponding to a fixed material point) $D\left(\rho v_{i}\right) / D t$ :

$$
\frac{D\left(\rho v_{i}\right)}{D t}=\left.\frac{\partial\left(\rho v_{i}\right)}{\partial t}\right|_{\xi}+\left(v_{j}-v_{j}^{m}\right) \frac{\partial\left(\rho v_{j}\right)}{\partial x_{i}}
$$

The derivatives on the right-hand side correspond to a generic point on the mesh, with the mesh-referential derivative and the convective term.

Using the linearization of Eq. 4 we obtain from Eq. 1 and Eq. 2 the system of ordinary differential equations in the form:

$$
{ }^{t} \mathbf{M}_{(1)} \mathbf{V}^{*}+{ }^{t} \mathbf{K}_{(1)_{v v}} \Delta \mathbf{V}+{ }^{t} \mathbf{K}_{v p} \Delta \mathbf{P}={ }^{t+\Delta t} \mathbf{F}_{(1)}-{ }^{t} \mathbf{F}_{(1)}
$$

and

$$
{ }^{t} \mathbf{M}_{(2)} \mathbf{V}^{*}+{ }^{t} \mathbf{K}_{(2) v v} \Delta \mathbf{V}={ }^{t+\Delta t} \mathbf{F}_{(2)}-{ }^{t} \mathbf{F}_{(2)}
$$

\subsection{Numerical procedure for solid-fluid interaction}

When fluid is acting on a solid producing surface loads and deformation of the solid material, the fluid-structure interaction is implemented. The opposite also occurs, i.e. deformation of a solid affects the fluid flow. There are two approaches for the Finite Element (FE) modeling of solid-fluid interaction problems: a) strong coupling method, and b) loose coupling method. The solid and fluid domains are modeled as one mechanical system in the first approach. In the second approach, the solid and fluid are modeled separately and the solutions are obtained with different FE solvers, but the parameters from one solution which affect the solution for the other medium are transferred successively. If the loose coupling method is employed, the systems of balance equations for the two domains are formed separately and there are no such computational difficulties. Hence, the loose coupling method is advantageous from the practical point of view and there is further description of this method. As stated above, the loose coupling approach consists of the successive solutions for the solid and fluid domains. A graphical interpretation of the algorithm for the solid-fluid interaction problem is shown in Fig. 3 (Filipovic et al. 2006). 


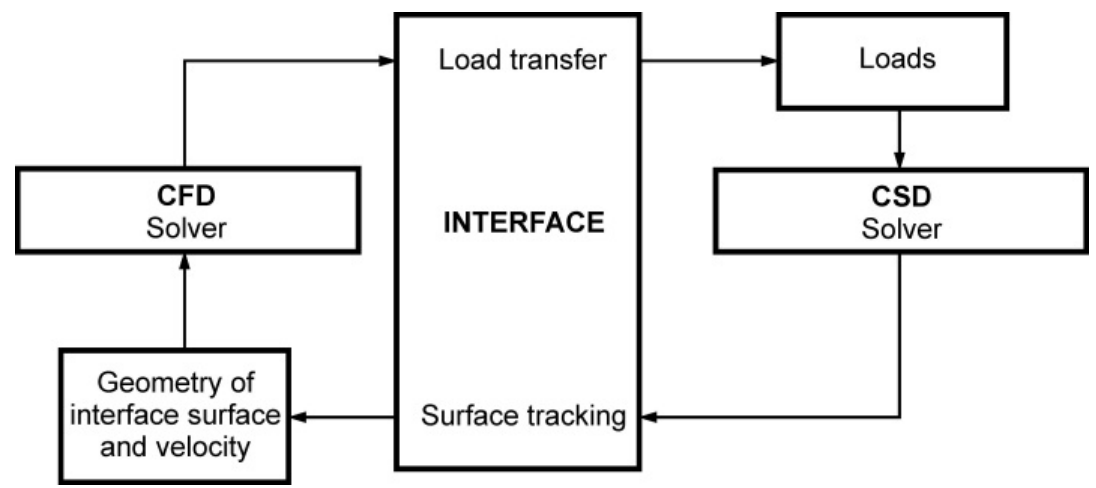

Fig. 3. Block-diagram of the solid-fluid interaction algorithm information and transfer of parameters between the CSD (computational solid dynamics) and CFD (computational fluid dynamics) solvers through the interface block

For coupling of cupula deformation and endolymph flow, fluid-structure interaction was implemented. Cupula was modeled as an elastic 3D membrane with 8-node finite element and endolymph domain as 3D 8 -node finite elements.

\section{Results}

Specific patient geometry was reconstructed from DICOM images (Fig. 4). Velocity distribution with one otoconia particle inside SCC has been presented in Fig. 5. A different head motion can be used to acquire the response for all three SCC as shear stress distribution, velocity, cupula deformation and drag force on the wall.

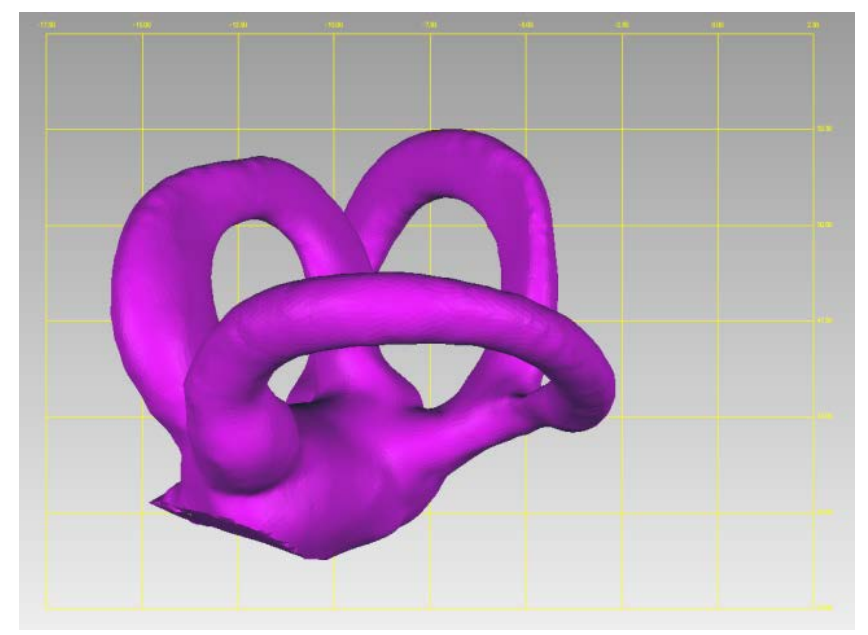

Fig. 4. Geometry for three SCC generated from original DICOM images 


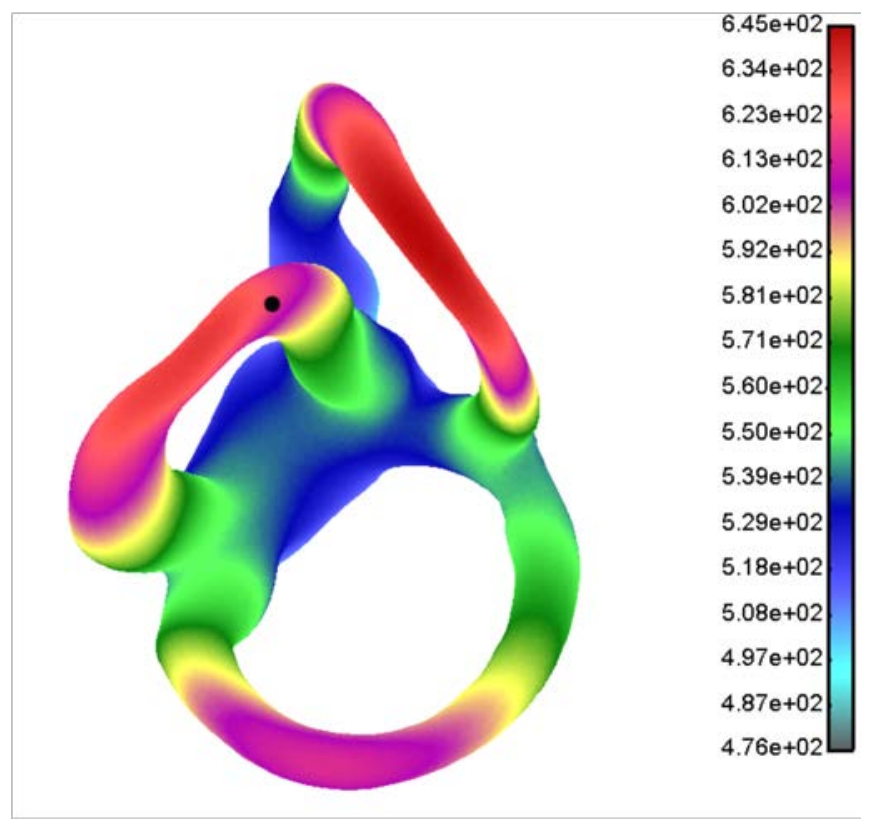

Fig. 5. Fluid velocity distribution with one otoconia particle for real patient specific geometry of three SCC for prescribed head motion

The head impulse test (HIT) is a useful bedside test to identify peripheral vestibular disease (Rabbitt et al. 1994, 1999, 2003, 2004). Head, eye and cupula deformation diagrams during HIT test are presented in Fig. 6.

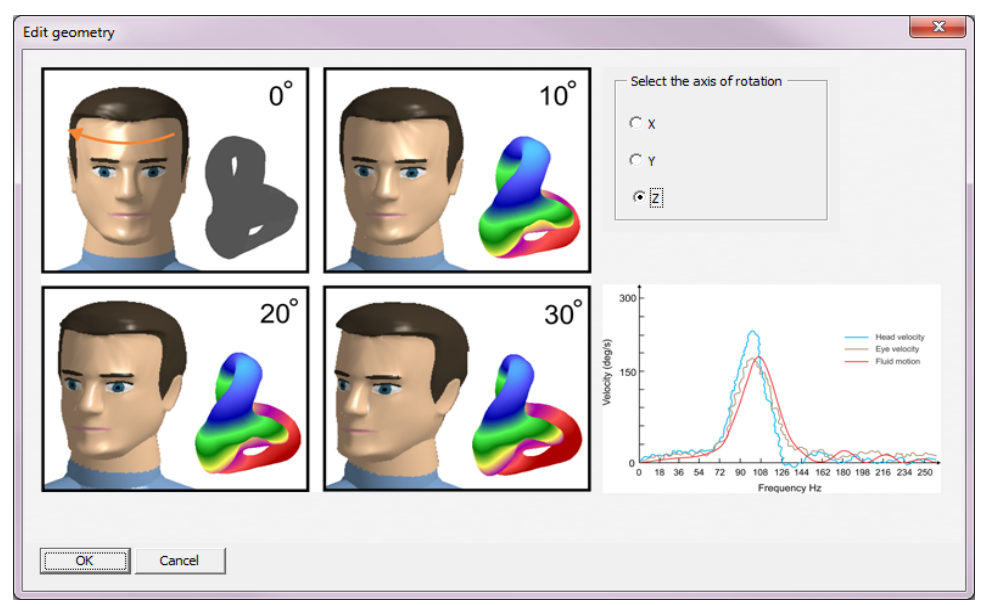

Fig. 6. Head, eye and cupula deformation diagrams during HIT test

Numerical model of fluid-structure interaction with endolymph fluid and cupula membrane solid domain was implemented. Also particle tracking algorithm for otoconia particle motion as well as fluid-structure interaction with particle-fluid domain is used. 
Experimental and numerical solution for HIT test and cupula deformation for head manoeuvre from 0 to $30^{\circ}$ is presented in the Fig. 7.

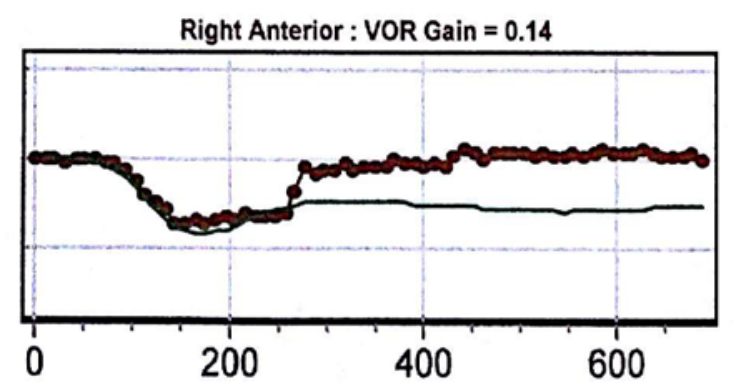

Fig. 7. VOR gain for Right anterior with patient

The corresponding head motion with canalith repositioning procedures moves the endolymph in all SCC canals. The flow induces the cupula deformation due to fluid forces which act on the cupula wall. Cupula volume displacement for the BPPV patient from Fig. 6 has been shown in Fig. 8.

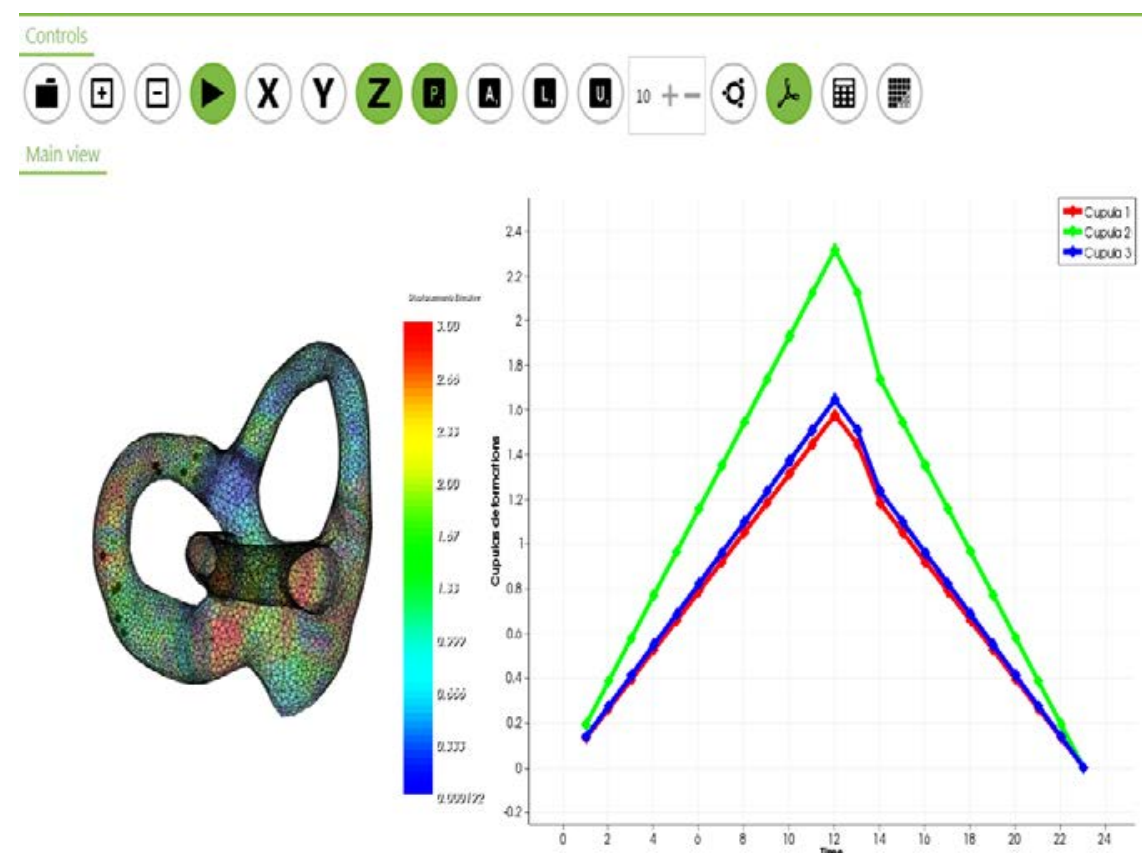

Fig. 8. Simulation of the otoconia particles motion and cupula deformation

\section{Conclusions}

In this study three-dimensional biomechanical model of the SCC is presented. Fluid motion, otoconia interaction with wall, fluid and cupula as well as cupula elastic deformation are described with corresponding numerical procedures. Simulation of many dynamics position of 
head with this model can give very precise position of fluid and simulate eye nystagmus with cupula deflection. We compared experimental and numerical solution for HIT test and cupula deformation for head manoeuvre from 0 to $30^{\circ}$. This can help in better diagnostic process for BPPV disease.

Acknowledgement This research is supported by the grants: EC FP7 610454 EMBalance project, III41007 and ON174028 Ministry of Education, Science and Technological Development of Serbia.

Извод

\section{Моделирање три полукружна канала код конкретног пацијента}

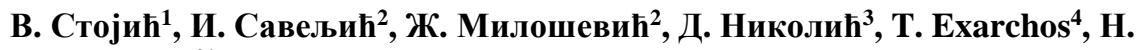 Филиповић ${ }^{2 *}$}

${ }^{1}$ Факултет медицинских наука, Универзитет у Крагујевцу, Србија имејл: vladislava.stojic@gmail.com

2 Факултет инжењерских наука, Универзитет у Крагујевцу, Србија имејл: fica@kg.ac.rs

${ }^{3}$ Истраживачко-развојни центар за биоинжењеринг БиоИРЦ, Крагујевац, Србија

${ }^{4}$ University of Ioannina, Грчка имејл: themis.exarchos@gmail.com

* главни аутор

\section{Резиме}

Полукружни канали (ПКК) су флуидом испуњене структуре унутрашњег уха дизајниране да детектују циркуларно или кружно кретање. У овој студији смо моделирали тродимензионални биомеханички модел ПКК и поредили резултате са стварним пацијентом који има БППВ болест. Модел узима у обзир тродимензионалну флуид-солид интеракцију са честицама, зидовима, деформацијама купула и струјањем ендолимфе. Потпуне Навије-Стоксове једначине су коришћене за решавање домена флуида са АЛЕ формулацијом за кретање мреже. За деформацију купуле са спрезањем струјања флуида коришћена је солид-флуид интеракција. Нумерички резултати су поређени са реалним експериментом на пацијенту за БППВ тест, за деформацију купуле и кретање главе од 0 до 30 степени. Приказани резултати могу се користити за боље разумевање и дијагностику БППВ болести.

Кључне речи: биомеханички модел ППК, флуид-солид интеракција, БППВ, седиментне честице 


\section{References}

Baloh RW, Jacobson K, Honrubia V (1993). Horizontal semicircular canal variant of benign positional vertigo, Neurology 43, pp. 2542-2549.

Berthoz A (2002). The sense of movement. Harvard University Press.

Filipovic N, Mijailovic S, Tsuda A, Kojic M (2006). An Implicit Algorithm within the Arbitrary Lagrangian-Eulerian Formulation for Solving Incompressible Fluid Flow with Large Boundary Motions, Comp. Meth. Appl. Mech. Engrg., 195, pp. 6347-6361.

Mergner T, Rosemeier T (1998). Interaction of vestibular, somatosensory and visual signals for postural control and motion perception under terrestrial and microgravity conditions: a conceptual model. Brain Research Review 28, pp.118-135.

Nuti D, Agus, G, Barbieri MT, Passali D (1998). The management of horizontal-canal paroxysmal positional vertigo, Acta Otolaryngol 118, pp. 455-460.

Pagnini P, Nuti D, Vannucchi P (1989). Benign paroxysmal vertigo of the horizontal canal, ORL J Otorhinolaryngol Relat Spec, 51, pp. 161-170.

Rabbitt RD, Boyle R, Highstein SM (1994). Sensory transduction of head velocity and acceleration in the toadfish horizontal semicircular canal. J. Neurophysiol., 72(2), pp. 1041-1048.

Rabbitt RD (1999). Directional coding of three-dimensional movements by the vestibular semicircular canals, Biol. Cybern., 80(6), pp. 417-431.

Rabbitt RD, Damiano ER, Grant JW (2003). Biomechanics of the vestibular semicircular canals and otolith organs. In Highstein, S. M. A. Popper, \& R. Fay (eds. The Vestibular System. Springer-Verlag New York, pp. 153-201.

Rabbitt RD et al. (2004). Hair-cell versus afferent adaptation in the semicircular canals. $J$. Neurophysiol., 93(1), pp. 424-436. 